\title{
Effect and Importance of Lighting Systems in School Libraries
}

\author{
Leila Hashempour
}

Lighting is the application of light in the most convenient way to visual perception on specific objects and surfaces (Sirel, 2001, s. 102). The use of lighting systems in buildings, especially in library buildings is a curtail issue. Proper use of lighting system is very important to the overall success of a library. Also, a well-designed lighting system in the libraries ensures a comfortable, bright, exciting or peaceful environment for the users. The main aim of this study is to examine the effects and importance of lighting system for the interior design of school libraries.

In this study, based on available literature, first of all the lighting sources and kinds will be explained. According to the basic principles of the library lighting system recommendations will be included in this regard. Proper lighting will be discussed according to school libraries sections. Lighting effects and importance in school libraries will be explained. Finally, according to the results general recommendations will be made about the subject.

Keywords: Lighting system, Illumination, Libraries, School libraries.

\section{Introduction}

L ighting is the application of light in the most convenient way to visual perception on specific objects and surfaces. The purpose of lighting is to make environment and objects visible by illumination source (Sirel, 2001, s. 102). Light can affect people psychologically and physically, and different reactions can emerge in response to different lights. Obviously, light indirectly affects the norms, actions, reactions and behaviors of the individual.

Lighting has long been a main environmental problem in buildings especially libraries. Therefore, it is understood that the lighting element should be examined seriously in order to make a building useful, aesthetic and attractive. Overall success of a library is related to some elements which one of them is lighting. Useful lighting design in libraries is the most important result of both art 
designer and technical skill. Lighting system in library buildings affects both users and workers. Users will stay longer in library and use the library more frequently. Also, library staff will be happier at work places. Otherwise, negative effects and impacts such as being less productive among library staff will be appear.

School libraries serve many functions to special groups of people. These libraries sometimes are just simple rooms with just a small reading space with some book stacks and sometimes are completely complex learning areas and resources with a circulation and service desk, conference room, exhibition and display sections and etc. These kinds of environments should foster reflection, understanding, and learning in a comfortable and welcoming area. Each of the areas requires different types and amounts of lighting. Designing a proper lighting system to supply properly all the activities which take place in school libraries is expensive and complex.

\section{Lighting Types}

According to American Lighting Association (2017), there are three types of lighting that work with each other in an area. A proper lighting combines all three types of light.

1. Ambient (general lighting): provides an area with total illumination. People can move easily and safety throughout the spaces by this kind of lighting. It can be accomplished with indoor and outdoor lighting like ceiling mounted fixture, chandeliers, table lamp, track light, wall lighting, spotlight and hanging fixture.

2. Task lighting: helps a person carries out specific tasks such as reading, doing homework and playing games. Pendant lighting, down light or directional recessed fixture and desk or portable lamp provide task lighting.

3. Accent lighting: mainly is used to achieve a desired effect or to focus on an interest. A larger space impression is given by this type of lighting. Wall- mounted fixtures, track light, down light or directional recessed fixture provide accent lighting (American Lighting Association, 2017; Standard Pro, 2017).

There are four types of lighting based on the direction according to "The Lighting Handbook" (Zumtobel, 2017, ss. 22-23): Table 1 shows these types of lighting and their features 
Table 1. Lighting types and their features

\begin{tabular}{|l|l|l|}
\hline Lighting type & \multicolumn{1}{|c|}{ Features } & Energy Efficiency \\
\hline \multirow{5}{*}{ Direct lighting } & $\begin{array}{l}\text {-Direct light on the ceiling from the luminaires } \\
\text {-Under flat angles, glare repression is important } \\
\text {-Dark ceiling (cave effect) } \\
\text {-No shadows }\end{array}$ & High \\
\hline \multirow{5}{*}{$\begin{array}{l}\text { Indirect lighting } \\
\text { lighting }\end{array}$} & $\begin{array}{l}\text {-Workplaces indirectly are illuminated } \\
\text {-Height increase } \\
\text {-Glare-free lighting } \\
\text {-Random arranged of workplaces }\end{array}$ & Low \\
& $\begin{array}{l}\text {-Directly and indirectly, light is directed via the ceiling from } \\
\text { freestanding or suspended luminaries } \\
\text {-Pretty room visuals } \\
\text {-High user approval } \\
\text {-Good contrast ratios } \\
\text {-Flexible workplace layout with an indirect share of }>60 \%\end{array}$ & $\begin{array}{l}\text { Good combination of } \\
\text { lighting quality and } \\
\text { energy efficiency }\end{array}$ \\
\hline Mellow lighting & $\begin{array}{l}\text {-In ceiling-mounted luminaire, the advantages of direct-indirect } \\
\text { lighting are combined } \\
\text {-Probability of a free workplace scheme } \\
\text {-Glare-free lighting } \\
\text {-Impression of daylight }\end{array}$ & $\begin{array}{l}\text { Good combination of } \\
\text { lighting quality and } \\
\text { energy efficiency }\end{array}$ \\
\hline
\end{tabular}

\section{Lighting Sources}

Almost every electric light fixtures uses incandescent, fluorescent or high-intensity discharge light sources. In the lighting industry these sources are technically known as "lamps"; among the public they are called "light bulbs" (Malman, 2001, s. 3). Besides these electric light fixtures, daylight is also a source of light. Table 2 shows different types of lamp (Zumtobel, 2017, ss.90-95):

Table 2. Lamp types and their features

\begin{tabular}{|l|l|l|l|l|}
\hline \multicolumn{1}{|c|}{ Lamp type } & \multicolumn{1}{|c|}{ Usage } & \multicolumn{1}{c|}{$\begin{array}{c}\text { Color } \\
\text { Rending }\end{array}$} & Dimmable & \multicolumn{1}{|c|}{$\begin{array}{c}\text { Luminous } \\
\text { efficiency }\end{array}$} \\
\hline $\begin{array}{l}\text { Halogen } \\
\text { incandescent } \\
\text { lamps }\end{array}$ & $\begin{array}{l}\text { Decorative and hospitality application, } \\
\text { domestic and retail areas }\end{array}$ & Excellent & Dimmable & $\begin{array}{l}\text { Better than } \\
\text { incandescent lamps }\end{array}$ \\
\hline $\begin{array}{l}\text { Fluorescent } \\
\text { lamps }\end{array}$ & Effective wide-area lighting & $\begin{array}{l}\text { Good to very } \\
\text { good }\end{array}$ & Dimmable & High to very high \\
\hline $\begin{array}{l}\text { Compact } \\
\text { fluorescent } \\
\text { lamps }\end{array}$ & $\begin{array}{l}\text { Hospitality application, prestigious } \\
\text { and commercial areas }\end{array}$ & Excellent & Dimmable & High \\
\hline $\begin{array}{l}\text { Metal halide } \\
\text { lamps }\end{array}$ & $\begin{array}{l}\text { Spotlighting, industrial bays, retail } \\
\text { areas }\end{array}$ & $\begin{array}{l}\text { Good to very } \\
\text { good }\end{array}$ & $\begin{array}{l}\text { Not } \\
\text { dimmable }\end{array}$ & High \\
\hline
\end{tabular}




\begin{tabular}{|l|l|l|l|l|}
\hline $\begin{array}{l}\text { High-pressure } \\
\text { sodium } \\
\text { discharge } \\
\text { lamps }\end{array}$ & $\begin{array}{l}\text { Outdoor illumination, street lighting, } \\
\text { industrial bays }\end{array}$ & $\begin{array}{l}\text { Satisfactory } \\
\text { to poor }\end{array}$ & $\begin{array}{l}\text { Can be } \\
\text { dimmed in } \\
\text { steps }\end{array}$ & High \\
\hline $\begin{array}{l}\text { Light emitting } \\
\text { diodes (LEDs) }\end{array}$ & $\begin{array}{l}\text { Decorative and functional lighting, } \\
\text { indoor and outdoor areas }\end{array}$ & $\begin{array}{l}\text { Good to very } \\
\text { good }\end{array}$ & $\begin{array}{l}\text { Can be } \\
\text { dimmed as } \\
\text { required }\end{array}$ & Very good \\
\hline
\end{tabular}

Light bulbs are divided in two indoor and outdoor lighting groups. Some of the most common indoor light bulbs are Incandescent, Compact Fluorescent Light (CFL), and Light Emitting Diode (LED). Being much brighter and last longer makes outdoor lights different from indoors. Halogen bulbs, Metal Halide, High Pressure Sodium (HPS), Low Pressure Sodium (LPS), and LED Street Lamps are some of the outdoor lights (National Optical Astronomy Observatory, 2017).

Daylighting is the other source of lighting. It is the inclusion of natural lighting into interior areas and spaces. Daylighting can reduce energy consumption of artificial lighting during daytime (Country Wide Lighting Team, 2017, s. 14).

\section{Libraries Lighting System}

At first glance, lighting does not seem to be an important issue, but it is one of the most important and critical issues. The use of lighting systems in buildings, especially in library buildings is a curtail issue. Proper use of lighting system is very important to the overall success of a library. Useful library lighting design is the most important result of both art designer skill and technical skill. Proper lighting in library buildings affects both users and workers. Users will stay longer in library and use the library more frequently. Also, library personals will be happier at work places. Otherwise, negative effects and impacts such as being less productive among library staff and visiting library less and less will be appear.

Libraries existed many years before electricity. They had to function without any lighting systems and libraries had depended on daylighting. Flamed lighting and gaslight were not suitable option because they were so risky. Accidents like burning, Carbon Dioxide poisoning and explosions could destroy the entire library. Being open just during daylight hours was also another problem (Celsus, 2018). But these kinds of problems were solved by the invention of electricity and the light bulbs. 


\section{Light Quantity for Libraries}

Library lighting system which is composed of both electric sources and daylighting must provide sufficient levels of light in glare-free and comfortable manners. As an independent organization of professionals, the Illuminating Engineering Society (IES) sets lighting level for building spaces. The following table presents the illumination levels for library spaces (Dilaura, et al, 2011, ss. 952977).

Table 3. IES light levels for library spaces (Foot Candles)

\begin{tabular}{|l|c|c|}
\hline \multicolumn{1}{|c|}{ Space } & Minimum FC level & Average FC level \\
\hline Active book stacks & 6 & 20.5 \\
\hline Inactive book stacks & 5 & 7.5 \\
\hline Book repair and binding & 20 & 30 \\
\hline Cataloging & 20 & 30 \\
\hline Circulation desk & 20 & 30 \\
\hline Reference desk & 20 & 30 \\
\hline Computer areas & 20 & 30 \\
\hline Audiovisual areas & 20 & 30 \\
\hline Audio listening areas & 20 & 30 \\
\hline Reading (Fine detail items, small print) & 50 & 75 \\
\hline Reading (newsprint, magazines, keyboard) & 20 & 30 \\
\hline
\end{tabular}

Besides electric lighting libraries can save money and energy by using sunlight. To protect library materials sunlight must be controlled. So, north facing windows are useful. These kinds of windows provide not much direct light. With sort of overhangs, south facing windows can be useful too. It is better that all windows have sort of covers which can be adjustable to control daylight (Celsus, 2018). 


\section{Lighting for Book Stacks}

Book stacks illumination should be proper for both users and staff. The light quantity for active and inactive book stacks are given in table 3. There are a few different approaches to illuminating the book stacks of a library (Malman, 2001, ss. 9-11).

- Parallel scheme: In parallel scheme a single row of one lamp linear fluorescent fixtures are centered above each aisle. These fixtures can be suspended below the ceiling, recessed in the ceiling, or attached to the stacks. They should distribute light equally across the stacks with no dark areas at the top shelf and enough light reaching the bottom shelf. In spite of these attentions, this scheme has the potential to reduce energy use and makes intuitive sense.

- Perpendicular scheme: In perpendicular scheme rows of two-lamp linear fluorescent fixtures run at right angles to the book stacks. There is no need to center lights above the aisles, so this scheme can be coordinated with the ceiling grid. This scheme also work well with compact shelving. In comparison with parallel scheme, this scheme uses fewer fixtures, because of that it may be the lowest cost solution.

- Indirect scheme: In this scheme, lights are uses on top of the stacks or suspended from the ceiling. The illumination is very soft, because all the light is reflected off the ceiling, and finally the whole stacks appears to have a pleasant glow. The indirect scheme uses higher energy than the parallel or perpendicular schemes.

- Hybrid scheme: Sometimes the indirect and perpendicular schemes are combined. In this scheme rows of direct-indirect fixtures suspended perpendicular to the stacks. Hybrid scheme provides good lighting on stacks at equable cost and with acceptable energy use.

\section{Lighting in Reading and Staff Areas}

Lighting in reading and staff areas must be flexible to present and future tasks. There are two approaches to illuminating the reading and staff areas of a library (Malman, 2001, s. 13): 
- Indirect lighting: In the indirect lighting scheme, the light source is not visible. Instead of that, the light is reflected off the wall, ceiling or floor. The resulting reflected light is shadow free, inherently very soft, and low-glare.

- Direct lighting: To illuminate tables, direct lighting uses down lights. In down lights compact metal halide lamps or fluorescent and parabolic cones can be used. Also they can be rectangular or linear fluorescent fixtures with parabolic louvers. The parabolic cones and louvers prevents shallow viewing angles. They should be made of aluminum and they should have a semi specular finish to prevent the visibility of fingerprints or dirt.

Direct and indirect lighting some times are combined, this type of lighting should be seriously considered for reading and staff areas of all libraries.

\section{Lighting for Service Desk}

As seen in Table 3 for service desks, the IES recommends a lighting level of 30 foot-candles average, with attentive coordination of computer-screen orientations and locations to prevent reflected glare. Staff members may spend most of their working time at a service desk. Because of that they should be very comfortable (Brown, 2002, s. 120; Malman, 2001, s. 16).

\section{Lighting for Community Rooms}

According to IES, small conference rooms should have a lighting level of 30-40 foot-candles average, measured horizontally at desktop (Brown, 2002, s. 120). Large meeting or community rooms should have 30-40 foot-candles with all lights on, and separately controlled lighting for the

podium or front of room. Several different types of lighting in these rooms should be used to give flexibility (Malman, 2001, s. 16).

International Association of School Librarianship

https://www.iasl-online.org/ 


\section{Lighting Effect and Importance in School Libraries}

Before discussion about lighting effect and importance in school libraries, it is essential to discuss about lighting in school libraries. School libraries serve many functions and are high profile spaces. These libraries range from simple rooms with just a small reading space with some book stacks to completely complex learning areas and resources with a circulation and service desk, conference room, exhibition and display sections and etc. These environments should foster reflection and learning in a comfortable and welcoming area. Each of them requires different types and amounts of lighting. Designing a true lighting system to supply properly all the activities which take place in school libraries is expensive and complex.

Lighting has long been a main environmental problem in schools. In a 1986, Robert Rohlf states, "The area in which most mistakes are made in library planning is lighting". Lighting systems for school library facilities are often unnoticed and overlooked by school librarians and architects. Because lighting affects people both physically and psychologically, and the quality of light affects the quantity and performance of learning (Erikson and Markuson, 2007, s. 61).

As mentioned above, lighting is classified into two categories, electric and daylighting or natural light. New school libraries are preferred to design with daylighting sources like windows, skylights, clerestories or a combination of these in order to reduce energy costs and support the positive effect of daylighting on students' performance and achievement. Natural light should be supplemented by electric light because of some variables such as the time of day, the direction of incoming light, and weather conditions. The following are some foot-candle recommendations for different tasks:

- Service desks: 40-50;

- Reading and study areas: 30-60;

- Small-group study rooms: 30-40;

- Stack areas: 30;

- Computer use areas: 20-30;

- Multipurpose rooms: 30-50;

- Staff workrooms: 50;

- Instructional areas: 30-70 (Erikson \& Markuson, 2007, s. 63). 
All library areas can't be illuminated at the same level, because the cost of energy is a barrier to it, and on the other hand the same light level causes fatigue. There are some critical issues to consider in school library lighting system. Architect, lighting engineer and librarian need to cooperate to take these issues into account.

It is difficult to light stack and study areas of libraries. To provide uniform illumination for all shelves is so difficult too. Naturally stacks create shadows, perpendicular scheme will help to reduce the shadows which created by people standing at the shelves. If there is windows, the shelves can be located near windows and by using perpendicular scheme of lighting natural light will be come into the stacks. In areas with high ceilings indirect lighting can't provide enough illumination to tabletops. Sometimes study tables will attached task lighting fixtures solve the problems. In case of using table fixtures, durable switches or switches controlled from a remote location will be the best choice. Also, double pedestal fixtures with additional outlets will be economical and more useful (Brown, 2002, s. 119; Erikson \& Markuson, 2007, s. 64). Some of the other issues are as follows (Malman, 2001; Brown, 2002; Erikson \& Markuson, 2007; Zumtobel, 2017):

Glare is an important problem in libraries. It creates health problems like headache and stress. It damages books, too. Always, a low glare lighting system should be preferred. Particular attentions must be paid for lighting sources on computer screens and whiteboards. In front of a computer monitor or behind of it daylighting will cause glare. Direct light will reflect off them. So indirect lighting systems are the best scheme for computer areas. This scheme need to be equipped with aluminum parabolic louvers to limit brightness for these areas. For whiteboards, a track system or supplementary lighting will give more control over illumination and give the flexibility to control condition easily.

Before planning a lighting system, the total cost needs to be calculated. It includes purchase price, installation cost and maintenance cost of facilities. Another main issue is the lighting controls and the placement of them. Light controls (switches) should be operated easily and have a simple design. Controls should not be accessible in public, but staff should be able to access them easily.

International Association of School Librarianship https://www.iasl-online.org/ 
During power outages or when normal lights are turned off security lights operate. They should be placed at entrance of the libraries. Active areas should have lighting to withstand earthquakes. It is recommended that to avoid dim illumination for all areas of library as a general safety measure. The lighting system of the library should be done not only for the present time but also for the future. There should be flexibility of lighting in any areas of the library. For library lighting windows treatments is necessary to control daylighting and eliminate noise from outside. Windows should have blinds, draperies, or screens.

The more the students use the library, the better they learn. On the other hand, the number of visits to the library may play an important role in student achievement. Students' motivations, reactions, and sense of well-being are affected by the illumination and lighting levels of environment. According to Ruck (1989), different levels of illumination can be used to increase creativity and encourage productivity in offices, schools and libraries. When entering a school library, users especially students need sufficient light to better understand the environment. For this reason, the lighting system used in the library need to invite students to actively read, entertain, learn, and research. The school library should be considered as a classroom as well as a worm place of learning with spaces for individual and group uses. The facility which used in library should be flexible and customizable to assist various activities. Properly usage of natural and electric light can provide physiological and physical benefits to administrators, teachers, and students in libraries.

According to Veitch (2010), there are six categories of human necessities addressed by lighting like task performance, visibility, social behavior and communication, comfort and mood, safety and health, judgments and aesthetic. Juslen and Tenner (2005) have mentioned that productivity is possible via the following mechanism:

- Visual performance: When people can see the task clear definitely they work and perform that better.

- Visual comfort: By removing inconvenience glaring the performance will increase because of the concentration enhancement.

- Interpersonal relationship: When people can see each other better they can have more cooperation and better communication. 
To support the main mission of school libraries that means to encourage education and entertainment different lighting scheme should be used in different areas of a library. It is possible to increase or decrease the efficiency of the libraries with the lighting element. The success of library management and efficiency depends on a pleasant and beautiful environment that meets the needs and requirements of users. Of course, the creation and design of such an environment is one of the important objectives of the libraries. To achieve this goal, architects, librarians and engineers need to collaborate and exchange ideas.

\section{Results and Recommendations}

In the school libraries, communication is made between students, staff, and librarians, and a convenient environment for the user to study, research and leisure is provided. In such environments, the information and research needs of the users as well as the aesthetic, pleasure, entertainment and peaceful needs are met. The successful library should identify and meet the needs and demands of its target mass in a positive and appropriate manner and apply different methods to meet them. Lighting systems designed for library buildings are important for providing visual comfort conditions and energy conservation. In libraries, reading areas need to be carefully designed in this respect. In various sections of a library, according to area features and function appropriate lighting fixtures and schemes must be selected. Therefore:

1. In a library properties of functions should be reviewed;

2. The main cooperation with related bodies should be determined;

3. By considering the psychological effects of the lighting, appropriate lighting systems should be determined for the area;

4. According to library budget, proper and essential equipment should be purchased;

5. Selected systems should be examined on a pilot and applied to the actual building.

According to the obtained results, the following general recommendations can be made.

- In this study, according to functional characteristics for different parts of school libraries appropriate lighting was proposed based on the literature. The light reflection factor, 
climate conditions and also curriculum are important issues to be examined in future studies.

- The fact that modern technologies reveal different influences in almost every field has even more impact on libraries. Studying the new technologies effects on light, illumination and color in interior design of libraries from different dimensions is an important consideration that should take into account to meet the growing needs of library users.

- The selection of the lighting system for school library buildings is a situation that needs to be considered more carefully than the other buildings. Determining the criteria that affect the lighting system of school libraries helps to fulfill space functions with ease.

- It is necessary to evaluate the lighting system preferred by the libraries. User satisfaction is required to determine the expectations of staff and students for the system used. 


\section{References}

American Lighting Association (2017). Basic types of lighting. Retrieved February 27, 2018 from https://www.americanlightingassoc.com/Lighting-Fundamentals/3-Types-ofLighting.aspx.

Brown, C.R. (2002). Interior design for libraries: drawing on function \& appeal. Chicago and London: American Library Association.

Celsus (2018). Lighting in libraries. Retrieved March 3, 2018 from https://libraryarchitecture.wikispaces.com/Lighting+for+Libraries.

Country Wide Lighting Team (2017). Lighting standard. Retrieved February 2, 2018 from http://www.colliergov.net/your-government/divisions-a-e/county-manager-soffice/standards

Dilaura, D. I.; Houser, K.W.; Mistrick, R.G.; \& Stelly, G.R. (2011). The lighting handbook. 8'th edition. New York: IES.

Erikson, R.; Markuson, C. (2007). Designing a school library media center for the future. Second edition. Chicago: American Library Association.

Juslen, H. and Tenner, A. (2005). Mechanisms involved in the enhancing human performance by changing the lighting in the industrial workplace. International Journal of Industrial Ergonomics, 35(9), 843- 855.

Malman, D. (2001). Lighting for libraries. Retrieved January 15, 2018 from http://www.iar.unicamp.br/lab/luz/ld/Arquitetural/diversos/Lighting\%20for\%20Libraries. pdf.

National Optical Astronomy Observatory (2017). Types of lights. Retrieved January 18, 2018 from https://www.noao.edu/education/QLTkit/ACTIVITY_Documents/Energy/TypesofLights. pdf.

Ruck, N. C. (1989). Building design and human performance. New York: Van Nostrand.

Sirel, Ş. (2001). Aydınlatma ve Mimarlık. Tasarım, 110, 98-105.

Standard Pro. (2017). 3 basic types of lighting. Retrieved February 20, 2018 from http://www.standardpro.com/3-basic-types-of-lighting/

Veitch, J. A. (2001). Psychological processes influencing lighting quality.Journal of the Illuminating Engineering Society, 30(1), 124-140.

Zumtobel (2017). The Lighting Handbook. Dornbirn: Zumtobel Lighting GmbH.

International Association of School Librarianship

https://www.iasl-online.org/ 